\title{
Geospatial Assessments of DNA Adducts in the Human Stomach: A Model of Field Cancerization
}

\author{
Yuji Iwashita 1,*(D), Ippei Ohnishi ${ }^{1,2}$, Yuto Matsushita 1,3, Shunsuke Ohtsuka 1,4, Takashi Yamashita 1,5, \\ Keisuke Inaba ${ }^{6}$, Atsuko Fukazawa ${ }^{6}$, Hideto Ochiai ${ }^{6}$, Keigo Matsumoto ${ }^{6}$, Nobuhito Kurono ${ }^{7}$, \\ Yoshitaka Matsushima ${ }^{8}$, Hiroki Mori ${ }^{4}$, Shioto Suzuki ${ }^{2}$, Shohachi Suzuki ${ }^{6}$, Fumihiko Tanioka ${ }^{2}$ \\ and Haruhiko Sugimura $1, *$ (i)
}

1 Department of Tumor Pathology, Hamamatsu University School of Medicine, 1-20-1 Handayama, Higashi-ku, Hamamatsu, Shizuoka 431-3192, Japan; ippeiohnishi@hospital.iwata.shizuoka.jp (I.O.); yuto.m@hama-med.ac.jp (Y.M.); d15027@hama-med.ac.jp (S.O.); D15025@hama-med.ac.jp (T.Y.)

2 Pathology Division, Iwata City Hospital, 512-3 Ohkubo, Iwata, Shizuoka 438-8550, Japan; shiosuzuki-path@umin.net (S.S.); ft-patho@hospital.iwata.shizuoka.jp (F.T.)

3 Department of Urology, Hamamatsu University School of Medicine, 1-20-1 Handayama, Higashi-ku, Hamamatsu, Shizuoka 431-3192, Japan

4 Hamamatsu Medical Center, 328 Tomitsuka-cho, Naka-ku, Hamamatsu, Shizuoka 432-8580, Japan; mori_h@hmedc.or.jp

5 First Department of Surgery, Hamamatsu University School of Medicine, 1-20-1 Handayama, Higashi-ku, Hamamatsu, Shizuoka 431-3192, Japan

6 Surgery Division, Iwata City Hospital, 512-3 Ohkubo, Iwata, Shizuoka 438-8550, Japan;

check for updates

Citation: Iwashita, Y.; Ohnishi, I.; Matsushita, Y.; Ohtsuka, S.; Yamashita, T.; Inaba, K.; Fukazawa, A.; Ochiai, H.; Matsumoto, K.; Kurono, N.; et al. Geospatial Assessments of DNA Adducts in the Human Stomach: A Model of Field Cancerization. Cancers 2021, 13, 3728. https://doi.org/10.3390/

cancers 13153728

Academic Editor: Alain P. Gobert

Received: 1 May 2021

Accepted: 22 July 2021

Published: 24 July 2021

Publisher's Note: MDPI stays neutral with regard to jurisdictional claims in published maps and institutional affiliations.

Copyright: (c) 2021 by the authors. Licensee MDPI, Basel, Switzerland. This article is an open access article distributed under the terms and conditions of the Creative Commons Attribution (CC BY) license (https:/ / creativecommons.org/licenses/by/ $4.0 /)$. kinaba@seirei-fuji.com (K.I.); akko@hospital.iwata.shizuoka.jp (A.F.); hydeochi@hmedc.or.jp (H.O.); keigo422@live.jp (K.M.); shohachi88@hotmail.com (S.S.)

7 Department of Chemistry, Hamamatsu University School of Medicine, 1-20-1 Handayama, Higashi-ku, Hamamatsu, Shizuoka 431-3192, Japan; chrono@hama-med.ac.jp

8 Department of Agricultural Chemistry, Tokyo University of Agriculture, 1-1-1 Sakuragaoka, Setagaya-ku, Tokyo 156-8502, Japan; ym205308@nodai.ac.jp

* Correspondence: 07485223@hama-med.ac.jp (Y.I.); hsugimur@hama-med.ac.jp (H.S.); Tel.: +81-53-435-2220 (Y.I. \& H.S.)

Simple Summary: The geospatial distribution of DNA adducts, the presumable origins of mutations causing human cancers in the stomach was described. In human stomach resections for gastric cancer, seven different DNA adducts, C5-methyl-2'-deoxycytidine, 2'-deoxyinosine, C5-hydroxymethyl-2' deoxycytidine, N6-methyl-2'-deoxyadenosine, 1,N6-etheno-2'-deoxyadenosine, N6-hydroxymethyl$2^{\prime}$-deoxyadenosine, and C8-oxo- $2^{\prime}$-deoxyguanosine, were identified in various parts and zones of the human stomach, namely, the upper, middle and lower zones, anterior and posterior walls, and lesser and greater curvatures. This DNA adductomics approach will reveal the exposure and risk of individual gastric mucosa in humans. Basic information on multiple DNA adduct profiles in terms of the correlation with the preferred locations of gastric cancer in the stomach will provide the reality of "field cancerization" in human gastric carcinogenesis.

Abstract: Background: Field cancerization is a popular concept regarding where cancer cells arise in a plane, such as the opened-up gastrointestinal mucosa. The geospatial distribution of DNA adducts, some of which are believed to initiate mutation, may be a clue to understanding the landscape of the preferred occurrence of gastric cancer in the human stomach, such that the occurrence is much more frequent in the lesser curvature than in the greater curvature. Methods: Seven DNA adducts, C5-methyl-2'-deoxycytidine, 2'-deoxyinosine, C5-hydroxymethyl-2'-deoxycytidine, N6methyl-2'-deoxyadenosine, 1,N6-etheno-2'-deoxyadenosine, N6-hydroxymethyl-2' -deoxyadenosine, and C8-oxo-2'-deoxyguanosine, from different points and zones of the human stomach were semi quantitatively measured by liquid chromatography/tandem mass spectrometry. The differences in the quantity of these DNA adducts from the lesser and greater curvature, the upper, middle and lower third zones, the anterior and posterior wall of the stomach, and the mucosae distant from and near the tumor were compared to determine whether the location preference of cancer in the stomach could be explained by the distribution of these DNA adducts. Comparisons were conducted 
considering the tumor locations and operation methods. Conclusions: Regarding the DNA adducts investigated, significant differences in quantities and locations in the whole stomach were not noted; thus, these DNA adducts do not explain the preferential occurrence of cancer in particular locations of the human stomach.

Keywords: DNA adduct; DNA adductome; DNA adductomics; mutagen; exposure; stomach; gastric cancer; liquid chromatography/tandem mass spectrometry

\section{Introduction}

Gastric cancer is the third leading cause of cancer death worldwide [1]. There are regional differences in the incidence of gastric cancer, which occurs frequently in Asia [1]. Although the cause of regional differences is not fully understood, environmental factors are believed to be primarily important in gastric carcinogenesis except in rare cases of a genetic cause [2], mainly because of the time trend of prevalence and immigration studies [3-5]. Several chemical carcinogenesis models were developed by Japanese investigators [6,7], but extrapolation of these experimental findings to human stomach carcinogenesis is still elusive. On the other hand, Helicobacter pylori (HP) definitely plays an important role in certain steps of gastric carcinogenesis, especially in Japan [8,9], although only a small portion of subjects with HP infections develop gastric cancer [10]. An analysis of human gastric carcinogenesis would provide a model to elucidate the genetic and environmental contributions.

\section{Gastric Cancer Risk}

Several genetic risk loci of gastric cancer are known, ranging from the historically identified blood type A [11] to the markers discovered through genome-wide association study, including prostate stem cell antigen (PSCA), mucin 1 (MUC1) and other genes [12-15]. As stated in the previous section, immigration studies of Japanese populations to Hawaii or Brazil $[3,4,16,17]$ verified that the main risks for gastric cancer are environmental and lifestyle factors, which include chronic atrophic gastritis [18] and diet, such as salt intake [19]. Recent clean-up of HP has already contributed to decreasing the prevalence of gastric cancer in Japan [9]. Chemical and physical carcinogenesis of the stomach has also been investigated, and several culprits have been proposed, such as talc in refined rice [20]. In particular, based on epidemiological and experimental data, nitroso compounds generated in the stomach are believed to play an important role in human gastric carcinogenesis [21-24]. Although some of the mechanisms are not completely understood, these risk factors are thought to induce the development of somatic mutations in genes related to carcinogenesis.

\section{Mutation Spectrum and Mutational Signature of Gastric Cancer}

\subsection{Mutation Spectrum}

There are many types of mutations. Even in the case of substitution mutations, three types of substitutions are possible starting from each of the four bases. Based on the complementarity of double-stranded DNA, the combinations can be summarized by six types of substitutions. Mutations observed in individual tumors can be classified into these types. The distribution of these mutation types can be treated as a particular profile, "the mutation spectrum" [25]. If the cause of the mutation is different, the mutation spectrum is also expected to be different. Among the mutations found in gastric cancer, transitions such as C:G to T:A are most prevalent, and such changes in GC and non-GC regions are thought to have different causes. It has been presumed that the C:G to T:A transition that occurs at the $\mathrm{CpG}$ site found in gastric cancer originates from the spontaneous deamination of C5-methyl-dC by reactive oxygen species [26-29]. These mutations in gastric cancer are thought to be caused by inflammation-related carcinogenic mechanisms such as HP. 
Another pathway to gastric cancer is mutation by alkylating agents generated by nitroso compounds and gastric conditions, in other words, derived from substances present in food and other environments [30,31]. Many of the mutations present in non-GC promoters have been attributed to alkylation of the base. The model of gastric carcinogenesis caused by alkyl compounds has been proposed in Japan using animal experiments [6], but extrapolation to human gastric carcinogenesis has not been fully addressed.

\subsection{Mutational Signature}

The mutation spectrum focuses only on the bases to be substituted, usually in the genes known to be mutated most frequently in human tumors. In the era of massive parallel sequencing, mutational investigation of the comprehensive genome in human stomach cancer expands the horizon of the genes mutated in gastric cancer [32], and the categorization of tumors based on the "mutational signature" has been developed as an analysis approach that also considers the bases before and after the substituted base [33,34]. Early studies applied mutational signatures mostly to gastric cancer exome data and showed that some gastric cancers had mutational signatures specific to repair abnormalities in DNA double-strand breaks, suggesting that the application of platinum therapy or PARP inhibitors may be effective [35]. Although there were certain quantitative differences and biases, some mutational signatures observed in gastric adenocarcinoma were shared by other gastrointestinal adenocarcinomas [36]. Recent pan-cancer analysis of the whole genome showed that gastric adenocarcinoma had several mutational signatures related to the deamination of 5-methylcytosine, APOBEC activity, reactive oxygen species, deficiency of homologous recombination or DNA mismatch repair derived from mutations in BRCA1 or POLD [37]. The prevalence of these mutational signatures and their proportion in the total number of mutations in an individual tumor are different, suggesting different backgrounds for individual instances of carcinogenesis. In general, mutations that appear to be due to loss of DNA repair gene function have relatively low prevalence but represent a relatively high proportion of all mutations in an individual. Some of the mutational signatures are reasoned to reflect the mutational process by distinctive cause, but gastric cancer has a less distinctive signature, although some features are reported [38]. In addition to these mutational signatures, some mutational signatures that show high prevalence within the population and high mutation rates in individual tumors have unknown causes. Intestinal metaplasia, usually distinct from authentic cancer, is known to have a low frequency of DNA mutations, and its mutational signature partially overlaps with the mutational signature of adjacent full-blown gastric cancer [39]. Most of the cancer genomic data to date have been biased towards individuals of European descent, but studies of the cancer genome in Africans and Asians are becoming increasingly important. Asians are known to have a high incidence of gastric cancer, and elucidation of the reason is a challenge. For example, regarding the association with HP, which is one of the important causes of gastric cancer, Shimizu et al. reported a specific mutation spectrum by the analysis of a small number of the cases associated with HP [40]. Recent analysis using hundreds of Japanese gastric cancer exomes discovered that a particular mutational signature is associated only with people who have both smoking and drinking habits [41]. Mutational signature analysis is expected to identify new causes of gastric carcinogenesis, but not all hypotheses about the causes of mutations derived from mutation spectrum analysis studies have been verified by current mutational signature analysis. There should be other molecular clues to focus on the ultimate cause of DNA damage and mutations.

\section{DNA Adducts as a Cause of Mutation}

\subsection{DNA Damage in Gastric Mucosae}

\subsubsection{Types of DNA Damage}

The gastric mucosa, like other organs, is subject to various types of DNA damage, including DNA single- or double-strand breaks and the formation of DNA adducts, by highly reactive chemicals generated externally or internally. This review focuses on DNA 
adducts that can cause DNA mutations in chemical carcinogenesis (Figure 1). DNA adducts are produced due to chemical damage caused by highly reactive substances derived from food and the environment or substances that exhibit increased reactivity after metabolic processes inside and outside the body. The products of enzymatic DNA modifications associated with epigenetic regulation, such as $\mathrm{C} 5$-methyl-dC, have chemical characteristics in common with DNA adducts in the sense of altered atypical nucleic acids. Depending on the chemical structure, the DNA adduct may cause incorrect base pairing or interfere with DNA polymerase during DNA replication. These factors inhibit accurate DNA replication and potentially cause DNA mutations. Regardless of mutagenicity, DNA adducts in cells are useful as indicators of exposure to factors associated with carcinogenesis. In addition, they are used to study the etiology of mutations as a result of chemical reactions that occur before mutations associated with carcinogenesis.

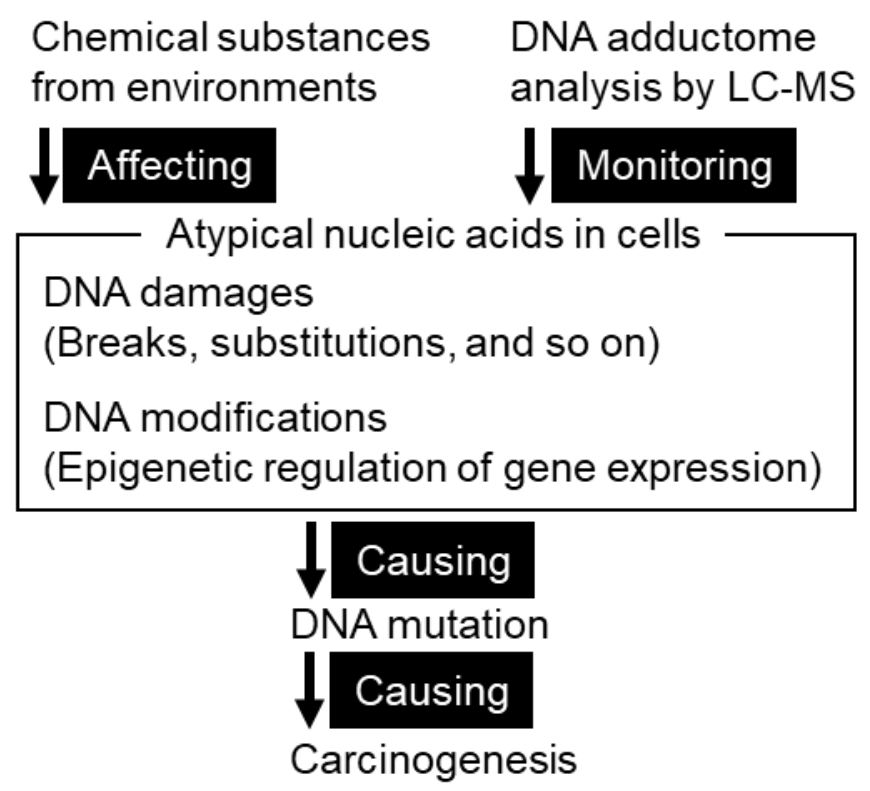

Figure 1. A schematic illustration of DNA adductome analysis to monitor DNA damages in chemical carcinogenesis. Many chemical substances affect DNA damages and DNA modifications. These atypical nucleic acids potentially cause DNA mutation and carcinogenesis. Using liquid chromatography coupled with mass spectrometry, the accumulation of DNA damages can be monitored by DNA adductome analysis.

\subsubsection{Methodology for Identification of DNA Adducts}

Historically, the ${ }^{32} \mathrm{P}$ postlabeling method has been widely used as a method for detecting DNA adducts [42]. Purified DNA is digested to monomeric nucleotides by enzymes and postlabeled by T4 polynucleotide kinase and $\left[\gamma_{-}{ }^{32} \mathrm{P}\right]$ ATP and then separated by thinlayer chromatography to distinguish DNA adducts from intact nucleobases that are present in large excess in cells. The ${ }^{32} \mathrm{P}$ postlabeling method is highly sensitive and is estimated to detect only one DNA adduct in the $10^{10}$ undamaged bases. However, the identification of the type of DNA adducts based on the results of the standard compounds used in parallel was ambiguous. Subsequently, a method was developed in which a single DNA adduct was targeted, well separated by high-performance liquid chromatography (HPLC), and identified by ultraviolet absorption or mass spectrometry. With a few exceptions, both the mass and the column retention time of each DNA adduct often vary, greatly improving the accuracy of substance identification. With the further development of methods for comprehensively identifying or quantifying intracellular molecules by mass spectrometry, such as proteomics and metabolomics, the DNA adductomics approach has also evolved [43,44]. 


\subsubsection{DNA Adductome}

A set of all DNA adducts present in cells is defined as a DNA adductome. The academic discipline or methodology that deals with the DNA adductome is called DNA adductomics. The advantage of performing liquid chromatography coupled with mass spectrometry as a DNA adductomics approach is to identify many types of DNA adducts with a degree of certainty and quantify them at the same time. The similarity to disciplines such as proteomics and metabolomics is that mass spectrometry is used to identify and quantify the relevant biomolecules as completely as possible. An important point common to these comprehensive analyses is the justification of peak determination. If available, standard compounds can be primarily used to identify the $\mathrm{m} / \mathrm{z}$, that is, the mass per number of charges observed in the mass spectrometry of DNA adducts. The standards are also useful to determine peak boundaries in LC-MS chromatograms, helping to distinguish between signal and noise. Information on the chemical standards of DNA adducts can be collected from research articles and reviews [45-48] and public or commercial databases such as PubChem and SciFinder. An international consortium deposited the mass spectrum of DNA adducts to a mass database [49]. Many chemical vendors respond to inquiries about compound synthesis. In the absence of standards, the signal intensity and frequency within the population are factors to consider when selecting peaks to be measured as potential DNA adducts. As the calculation of the peak area is affected by the drift of the column retention time, an appropriate signal threshold is also an issue. Signal normalization between samples is necessary because there are variations in measurement within the same day or between days.

DNA adductomics has several unique characteristics as an analytical experiment. Although a simple comparison is not possible, there are four types of intact nucleobases in the human genome and approximately 20 types of amino acids that constitute peptides, whereas there are over 200 types of DNA adducts with unique chemical structures derived from various mutagens [50]. Therefore, it is necessary to address the different degree of complexity from that of DNA sequencing and protein identification. In the multiple processes for the identification of DNA adducts, including DNA purification, DNA digestion and preprocessing for mass spectrometry, such as enzyme removal and concentration, effective methods vary depending on the chemical properties of each individual DNA adduct. The variables to consider include the material of the sample vial and the composition of the sample solvent. Optimal storage may vary because the chemical diversity of DNA adducts also affects their stability. Although it is a basic concept in scientific research, the need to process the sample groups to be compared in parallel and control the artificial variation is exceptionally strong. Signals from excess genomic DNA can interfere with the identification of DNA adducts based on $\mathrm{m} / \mathrm{z}$ and column retention time. However, naturally occurring isotopes from these intact deoxyribonucleosides are available for the normalization for the intraday and day-to-day variance in mass spectrometric measurements. Iatrogenic, artificial and other confounding factors, especially in human tissues, forced us to modify the DNA extraction protocol.

The data analysis of the DNA adductome is also unique. In general, DNA adducts have low abundance and low frequency. The distribution of the abundance of each DNA adduct in the population, such as a normal distribution or a Poisson distribution, is not yet fully understood. The optimization of statistical frameworks such as parametric or nonparametric methods in accordance with such situations is still an unsolved problem. The low abundance of DNA adducts raises the question of whether to include measured zero values in statistical tests, but no consensus has yet been formed. It is useful to perform both qualitative and quantitative analyses with transparency. Sensitivity management is required for qualitative analysis because its detection or the lack thereof alone may be meaningless due to variations in sensitivity between specimens and measurement days. On the other hand, avoiding normalization between specimens provides an advantage in qualitative analysis. Common DNA adducts that are detected in all samples, such as C5-methyl-dC and C5-hydroxymethyl-dC, cannot be qualitatively analyzed. Qualitative 
analysis is appropriate for DNA adducts that are expected to occur infrequently due to exposure.

\subsection{DNA Adduct Profile of Gastric Mucosae}

\subsubsection{Lipid Peroxidation-Induced DNA Adducts in Human Gastric Mucosa}

We applied a DNA adductomics method to DNA extracted from 22 gastric mucosae of Japanese and Chinese individuals and observed seven DNA adducts related to lipid peroxidation: 1,N6-etheno-2'-deoxyadenosine, butanone-etheno-2'-deoxycytidine, butanoneetheno- $2^{\prime}$-deoxy-5-methylcytidine, butanone-etheno- $2^{\prime}$-deoxyadenosine, heptanone-etheno2'-deoxycytidine, heptanone-etheno- $2^{\prime}$-deoxyadenosine and heptanone-etheno-2'deoxyguanosine [51]. These DNA adducts showed different abundances ranging from below the detection limit to 1 adduct $/ 10^{5}$ corresponding nucleobases in individuals. Although there was no clear association of these DNA adducts with HP infection or other clinicopathological information, the accumulation of these lipid peroxidation-related DNA adducts was different between the Japanese and Chinese gastric mucosae. The populationdependent differences in the abundance of DNA adducts suggest that the DNA adductome profile may reflect the genetic or environmental factors that characterize each population. Our evaluation also revealed the repair mechanism of these lipid peroxidation-related DNA adducts [52]. Examining eight DNA glycosylases, including OGG1, SMUG1, TDG, NEIL1, MUTYH, NTH1, MPG and UNG2, we confirmed the results of previous studies in which SUMG1 and MPG removed 3,N4-etheno-2'-deoxycytidine and 1,N6-etheno-2'deoxyadenosine, respectively [53,54]. The 3,N4-etheno-2'-deoxycytidine is another DNA adduct induced by lipid peroxidation. We also found that TDG was able to remove thymine that has mispaired with several lipid peroxidation-related DNA adducts. Mass spectrometric analysis showed that the global amount of 3,N4-etheno-2'-deoxycytidine was increased by knockdown of TDG protein in cultured cells. As part of the diverse DNA damage that occurs in the human gastric mucosa, DNA adducts may create populationor individual-specific carcinogenic conditions through a complex process involving DNA repair mechanisms.

4.2.2. Application of DNA Adductomics Technology to the Analysis of Cytosine Modifications in Gastric Cancer

DNA adductomics technology is applicable to enzymatically modified DNA. C5-methyl-2'-deoxycytidine is one of the most abundant DNA modifications and plays a pivotal role in the epigenetic regulation of gene expression [55]. This modified base is not considered a cause of DNA mutations associated with disturbed DNA replication. Since its chemical structure and properties are different from those of undamaged nucleobases, it can be measured by mass spectrometry, similar to other mutagenic DNA adducts. C5-hydroxymethyl-2'-deoxycytidine, C5-formyl-2'-deoxycytidine and C5carboxyl-2'-deoxycytidine are produced by the oxidation of methylated cytosine by multiple enzymes as a demethylation process. We performed DNA adductome analysis in human gastric mucosae to quantify these DNA methylation or demethylation-related atypical nucleobases [56]. C5-hydroxymethyl-2'-deoxycytidine was significantly decreased in the tumorous portion of gastric cancer. C5-methyl-2'-deoxycytidine was also moderately decreased in tumors, while C5-formyl-2'-deoxycytidine and C5-carboxyl-2'-deoxycytidine were barely detectable. The expression of several enzymes related to cytosine demethylation was notably decreased in gastric cancer compared with that in adjacent nontumor regions. TET1 expression and C5-hydroxymethyl-2'-deoxycytidine levels had a significantly positive correlation. TET1 had a greater effect on the increase in C5-hydroxymethyl-2'deoxycytidine in a cultured cell line. The altered amount of modified bases regulated by the activity of methylation and demethylation enzymes is considered to be one aspect of biomolecular transformation in tumors. 
4.2.3. Mass Spectrometric Profiling of DNA Adducts in the Human Stomach Associated with Damage from Environmental Factors

To further explore the DNA adducts observed in the human stomach, we analyzed gastric mucosae resected from gastric cancer or non-gastric cancer patients using widetargeted identification of DNA adducts by liquid chromatography coupled with mass spectrometry [57]. We identified seven DNA adducts including modified bases, C5-methyl$2^{\prime}$-deoxycytidine, 2'-deoxyinosine, C5-hydroxymethyl-2'-deoxycytidine, N6-methyl-2'deoxyadenosine, 1,N6-etheno-2'-deoxyadenosine, N6-hydroxymethyl-2'-deoxyadenosine, and C8-oxo-2'-deoxyguanosine, in the human stomach. N6-hydroxymethyl-2' deoxyadenosine was first observed in the human gastric mucosa and follows recent reports of its presence in tumor and nontumor portions of human lung tissue [58]. A comparison of multiple samples in each individual showed that the differences within the individual were small, but the differences between the individuals were large. The causes of individual differences are not fully understood, but some may reflect differences in genetic background and/or exposures that vary from individual to individual. In fact, individuals with a history of smoking and/or drinking had a high accumulation of 1,N6-etheno-2' deoxyadenosine. C5-hydroxymethyl-dC was high in the gastric mucosa of non-gastric cancer patients, low in the nontumor regions of gastric cancer patients, and even lower in the tumor regions. It is noteworthy that changes in the nontumor part of the gastric mucosa may be a precursor to carcinogenesis. There are certain correlations between the accumulation of different DNA adducts, and it is expected that DNA adducts are generated through multiple pathways. By accumulating these discoveries, we are evaluating whether the profile of the DNA adductome, along with DNA mutations and gene expression, will be important information for understanding the mechanism of carcinogenesis.

\section{Field Cancerization and DNA Adductomics in the Stomach}

\subsection{Pathology of Gastric Cancer}

\subsubsection{Practice in Gastric Cancer Management: Detection, Diagnosis, and Therapy}

The practice of gastric cancer management is different among countries depending on prevalence, detection system, and surgical management. Early detection is the norm in some countries, such as Japan, but in most countries, the targets of medical care are advanced-stage patients. Most gastric cancer is adenocarcinoma. The morphology of adenocarcinoma of the stomach has attracted many pathologists, and subtyping based on histopathology and morphology is still popular, from the dichotomy of intestinal vs. diffuse types in Laurén's classification [59] to classifications including papillary type [60-62] and other minor subtypes, such as chief-cell predominant type [63] and fetal-gut differentiation type [64]. Morphological recordings of early-stage gastric cancers are summarized in the Japanese Classification System [65], and the system has fundamentally influenced the WHO classification system [60] since the first edition [66]. Guidelines for therapies, from surgery to chemotherapy to molecular targeted or immune checkpoint inhibitor therapy, are proposed almost annually [67]. Molecular-level advances in terms of infection, intestinal metaplasia, oxidative stress as an initiating cause, and progression model are also detailed [68].

\subsubsection{Recent Molecular Characterization of Gastric Cancer}

The somatic driver mutations that cause carcinogenesis are thought to be acquired in each gastric cancer showing various pathological conditions. The classical method of classifying gastric cancer by acquired somatic mutations started with mutations in TP53 and $\mathrm{CDH} 1$ and expanded the target driver genes through systematic exome or wholegenome sequencing. Beginning with the discovery that mutations in the ARID1A [69] and RHOA [70,71] genes are frequently found in subgroups of gastric cancer, a comprehensive molecular classification of gastric cancer was performed in hundreds of people, subdividing gastric cancer into four types: Epstein-Barr virus-positive, microsatellite instable, genomically stable and chromosomally instable tumors [72]. Research on whole-genome 
analysis began with a small number of cases [32] and has now grown to the scale of hundreds [73], and it is ultimately becoming possible to classify driver genes of individual cases of gastric cancer. As mentioned above, classification using mutational signature analysis of gastric cancer is also actively performed [37]. The identification in tumors of driver mutations that caused carcinogenesis enables us to evaluate the relationship between each subtype and prognosis and the effectiveness of various treatment methods, for example, by the elucidation of the genes that define the response to preoperative chemotherapy [74]. Moreover, the information on molecular evolution and the heterogeneity of peritoneal carcinomatosis derived from gastric adenocarcinoma [75] and the association of epidemiologic and clinical risk factors with each subtype are current topics that many molecular biologists have reviewed extensively [76-79].

\subsection{Field Cancerization}

\subsubsection{Original Concept of Field Cancerization}

The concept of field cancerization was proposed by Slaughter in 1953 [80], taking oral squamous cell carcinoma as an example. The planes composing stratified squamous epithelium such as oral, esophageal and skin tissue are good examples of this model; the point in the plane with the highest exposure to carcinogenic risk undergoes the initiation of carcinogenesis: that is, when several areas or sites are occupied by cancers, multiple occurrences would be a better interpretation of this phenomenon than horizontal invasion by one group of tumor cells. The supposed density map of carcinogens would influence the selection of the point most vulnerable to carcinogenic effects in the plane of the mucosa or skin. Molecular events such as the spread of the TP53 mutation in the skin reflect field cancerization in molecular terms [81,82]. In addition to mutations, epigenetic changes in the field also provide important information on earlier changes in DNA, such as promoter methylation in "precancerous" and apparently unremarkable mucosa [83]. Mitochondrial DNA mutations [84], mutation burdens [85] and the expression of miRNAs [86] are also relevant to the field cancerization hypothesis. Recent deep sequencing in the "normal" area of the tissues found considerable evidence of mutations [87], some of which are clonal. These observations supported the spatial occurrence of mutation and evolutionary processes in the origin and development of human cancer [88]. The density of attributes that include carcinogens themselves, epigenetic lesions, microRNA and mitochondrial DNA mutations and various DNA mutations found in precancerous or apparently nontumor mucosa on the planes of the mucosa will reflect the preference of cancer occurrence in the gastrointestinal tract in terms of spatial locations. The significance of multisite sampling for ultrarare somatic mutations in noncancerous tissue in field cancerization theory is well recognized, but the profile of these mutations has not been fully linked to the profile of DNA adducts in situ as an initiation step of individual mutations.

\subsubsection{Field Cancerization of Gastric Mucosae and Preferential Cancer Location within the Stomach}

Gastric cancer is known to occur relatively often on the lesser curvature side or fundus [89-91]. Although it is hypothesized that the lesser curvature side is a path for food and is susceptible to various stimuli and damage, the cause of hot spots is not fully elucidated. It is also known that the characteristics of gastric cancer that occur in the cardia or non-cardia are different [92-95]. These matters related to field cancerization are also considered to be related to the recurrence of gastric cancer and the development of multiple tumors. To elucidate the topography and contiguous pathology of gastric cancer, multisite sampling is important. Although there is limited research on the altered abundance of biomolecules in gastric mucosae, the molecules and phenomena observed in different abundances in the gastric mucosa are diverse, including DNA mutations and the expression of genes, microRNAs [86,96] and circular RNAs [97]. The accumulation of genetic and epigenetic alterations in normal cells and consequent cancer risk have also been reported $[83,98,99]$. 
5.2.3. Mass Spectrometric Profiling of DNA Adducts in the Local Part of the Human Stomach

As described above, we have reported an interindividual variance in the accumulation of DNA adducts in human gastric mucosae [57]. Although we also showed that the intraindividual difference in DNA adducts was small, we reanalyzed all the available data according to their anatomical information. Seven DNA adducts observed in human gastric mucosae showed a wide range of molar ratios (1 DNA adduct $/ 10^{6}-10^{2}$ intact nucleosides), but there was no difference in the anatomical zone-specific accumulation of these DNA adducts (Figures 2 and 3). As alternative approaches to verify the association between the DNA adduct and gastric carcinogenesis, we are considering analyses limited to typical samples according to the location of the tumor or length from the tumor.

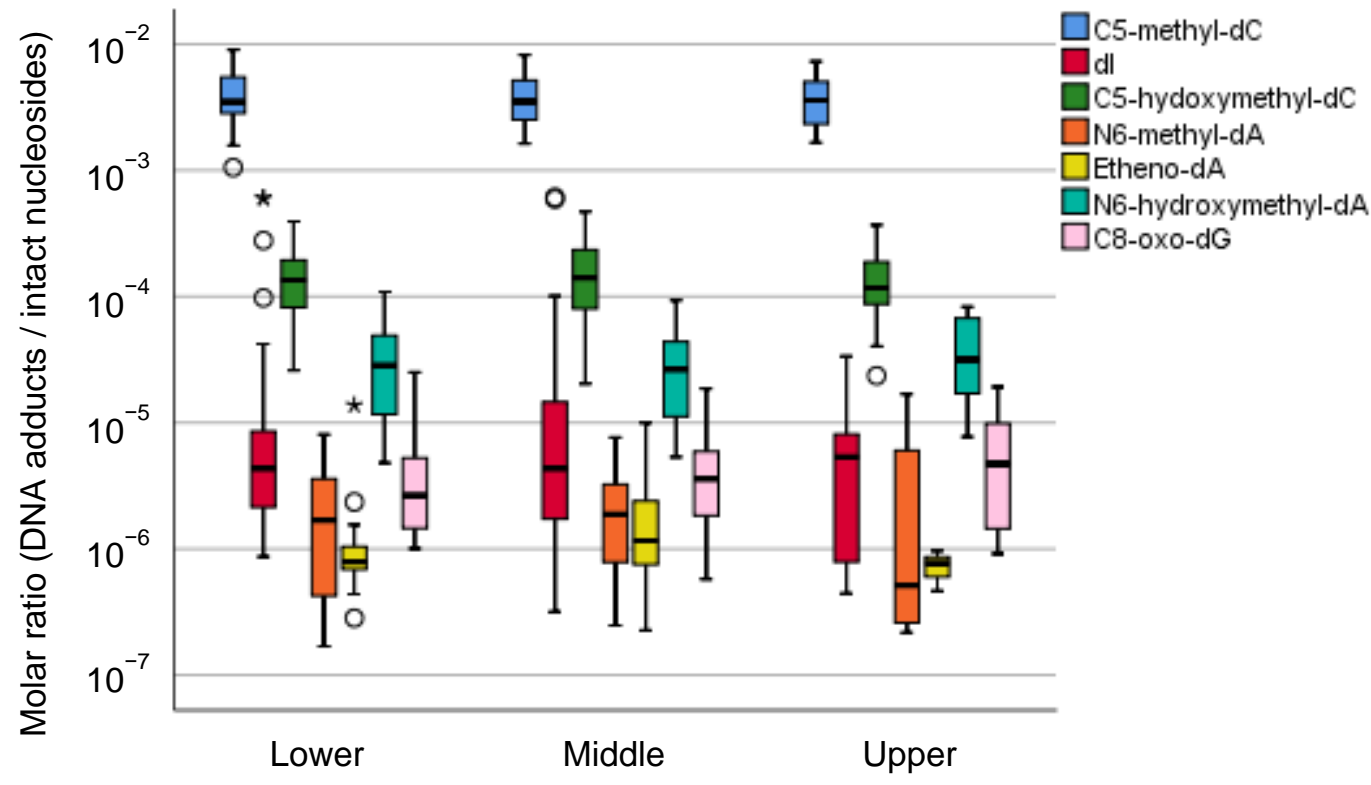

Figure 2. Distribution of DNA adduct profiles in the upper, middle, and lower parts of the gastric mucosae of gastric cancer patients. The molar ratio data of DNA adducts were retrieved from our previously published research [57]. The center line of the box indicates the median, and the top and bottom edges of the box indicate their interquartile ranges (IQR). The whiskers show the maximum or minimum values within a range of 1.5 times the IQR from the edge of the box. Outliers are indicated by circles $\left(^{\circ}\right)$ that are 1.5 to 3 times the IQR from the top or the bottom of a box and by stars $\left(^{*}\right)$ that are more than 3 times the IQR from the top or the bottom of a box. 


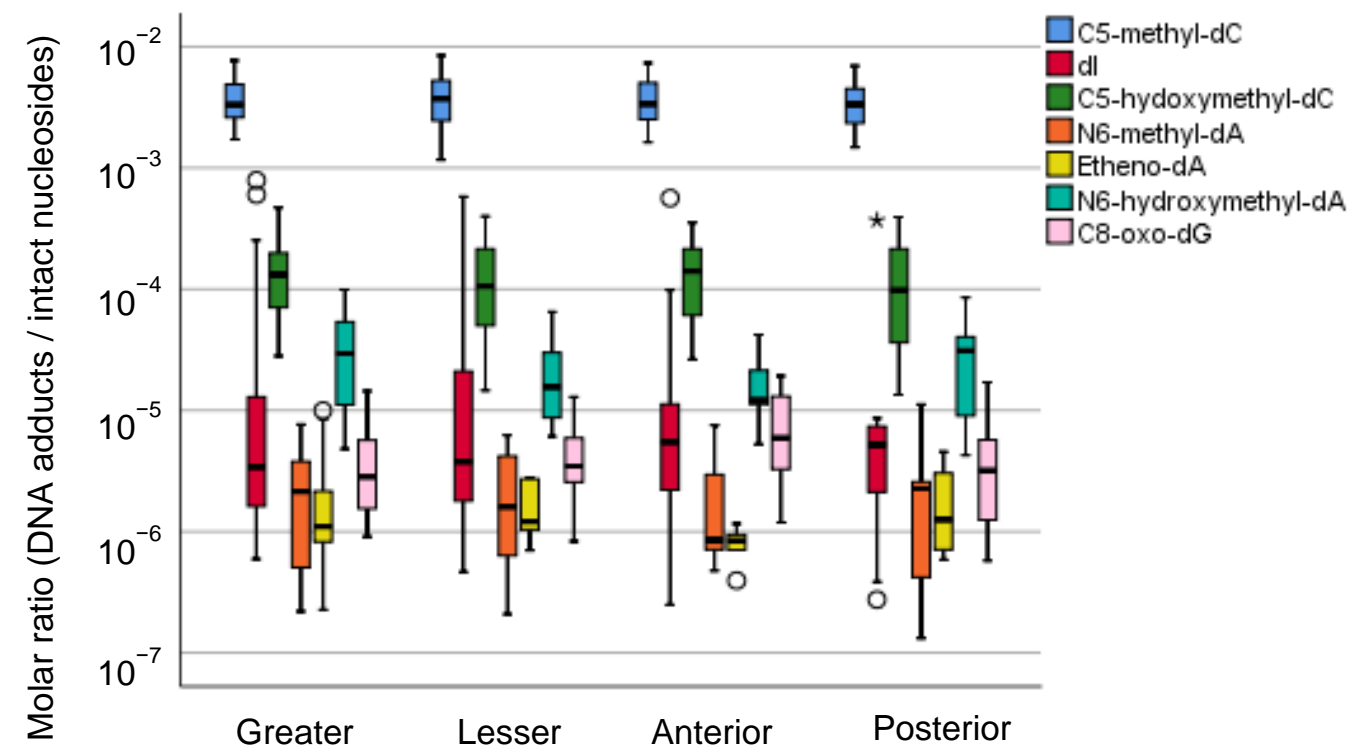

Figure 3. Distribution of DNA adduct profiles in the greater curvature, lesser curvature, anterior wall, and posterior wall of the gastric mucosae of gastric cancer patients. The molar ratio data of DNA adducts were retrieved from our previously published research [57]. The center line of the box indicates the median, and the top and bottom edges of the box indicate their interquartile ranges (IQR). The whiskers show the maximum or minimum values within a range of 1.5 times the IQR from the edge of the box. Outliers are indicated by circles $\left(^{\circ}\right)$ that are 1.5 to 3 times the IQR from the top or the bottom of a box and by stars $\left(^{*}\right)$ that are more than 3 times the IQR from the top or the bottom of a box.

\section{Perspectives to Evaluate the Field Cancerization of Gastric Cancer}

\subsection{Mutational Signature Analysis Combined with Experimental Exposure and Perturbation of} Genetic Backgrounds

The combination of new technologies is expected to accelerate the verification of the field cancerization hypothesis. Mutational signatures in genomics have begun to be cataloged in association with experimental exposure to environmental mutagens [100], which not only provides a history of exposures received by individuals but can also depict the situation of local exposure for each specimen. Similar studies have been conducted in mice, arguing that exposure to various chemical carcinogens does not produce fully unique mutational signatures, but only specific mutational signatures are observed [101]. Both the estimation of mutational signatures by deep sequencing and the direct identification of DNA adducts by mass spectrometry reveal the chemical changes that DNA has undergone, but only a few studies have combined the two methods [102-105]. It becomes important to understand the state before and after the occurrence of mutation by these two methods based on different principles. The consideration of the genetic background in mutagenesis using experimental exposure is also important. A pioneering study using C. elegans revealed mutational signatures after 20 generations of propagation or exposure to carcinogens in the background of deletions of 17 DNA repair genes related to nucleotide excision repair, base excision repair, DNA crosslink repair, DNA end-joining and apoptosis [106]. Mutational signatures induced by chemical carcinogens are augmented with a unique tendency by the deletion of specific DNA repair genes, indicating that both genetic background and the type of mutagen are important to elucidate the cause of the mutation. They extended their strategy to the deletion of mismatched repair genes such as MLH1 and achieved increased numbers of mutations with only 20 generations of propagation. This may mimic the condition of carcinogenic mutations in gastric cancer with microsatellite instability [107]. One of the three mismatch repair-related mutational signatures obtained by combining exomes of human gastric and colorectal cancer was consistent with that found in the nematode experiment. This has shown some of the usefulness of connecting the causes and 
results of mutation in experiments with model animals, but it is also true that mutational signatures of unknown etiology derived from human tumors remain. In a recent study with deletions of 53 DNA repair genes and exposures to 12 genotoxins, including ultraviolet B rays, ionizing radiation, alkylating compounds, aristolochic acid, aflatoxin B1 and cisplatin, $41 \%$ of experiments showed changes in the total number of mutations or mutational signatures [108]. In another cutting-edge study, knockouts of human-induced pluripotent stem cells in which 42 DNA repair or DNA replication genes were deleted by CRISPRCas9 underwent whole-genome sequencing to profile somatic mutations and understand mutation mechanisms that were previously unclear [109].

\subsection{Detection of DNA Damage by DNA Sequencing}

In the current mutational signature analysis by deep sequencing, in principle, it is not possible to know where DNA damage, including DNA adducts, was located on the genome before the formation of mutations. The genomic site of DNA damage can be determined through the purification of damaged DNA and deep sequencing. There are various methods for purifying damaged DNA, such as XR-seq $[110,111]$, which uses an antibody against TFIIH to collect oligonucleotides generated in the process of excision repair, and Damage-seq [110], which uses an antibody against damaged DNA such as cisplatin and ultraviolet photoproducts. The sequencing of bulky DNA adducts that inhibit DNA amplification required for deep sequencing was improved using translesion DNA synthesis polymerase as tXR-seq [112]. These methodologies were applied to evaluate drug resistance in oxaliplatin treatment [113] and transcription-coupled repair in ribosomal DNA [114]. For several mouse tissues, the integration of the sequencing of damaged DNAs and classical genome-wide characteristics derived from RNA-seq and ChIP-seq enabled us to reveal unprecedented genomic aspects of DNA damage influenced by gene expression and chromatin state [115]. As a different principle, single molecule real-time sequencing by a sequencer from Pacific Biosciences can also be used to sequence C5-methyl-2'-deoxycytidine and N6-methyl-2'-deoxyadenosine at 1-base resolution [116]. This method has been shown to be applicable to other damaged DNAs, such as C8-oxo-2'-deoxyguanosine, C8-oxo-2'deoxyadeosine, O6-methyl-2'-deoxyguanosine, N1-methyl-2'-deoxyadenosine, O4-methyl-2'-deoxythymidine, C5-hydroxy-2'-deoxycytidine, C5-hydroxy-2'-deoxyuridine, and C5-hydroxymethyl-2'-deoxyuridine or thymine dimers [117]. As another alternative method, it has been reported that the positions and sequences of thymidine analogs [118] and alkylated DNA [119] are determined by nanopore sequencing using MinION from Oxford Nanopore Technologies (Oxford, UK).

\subsection{Social and Scientific Significance of the Field Cancerization of Gastric Cancer}

Since these DNA sequencing-based methods limit the number of DNA adducts that can be analyzed at the same time, they are effective when used to complement the methods using mass spectrometry. To apply these techniques to verify the field cancerization hypothesis, it is necessary to collect multiple samples in continuous fields of tissues, but so far, examples of verifying local differences in DNA damage of the human gastric mucosa within one individual are still few. The regional specificity of DNA damage may be responsible for local carcinogenesis of gastric mucosae. After the further development of these technologies, it will be possible to catalog molecular types of DNA damage and their causative agents as clinical data through laboratory tests. These data help to control exposure and prevent carcinogenesis. In addition to the early detection of cancer and precise treatment specific to the individual, establishing a lifestyle that is less likely to cause cancer due to less DNA damage has important public health implications.

In this report, we present the spatial distribution of the seven DNA modifications in the stomach. These DNA modifications may be secondary products of chronic inflammation and continued exposure to reactive oxygen species. As far as these seven DNA modifications are concerned, no particular preference of the distribution was noted (Figures 2 and 3). According to Sasazuki et al. [120], smoking was associated with an in- 
creased risk of the differentiated type of distal gastric cancer; compared to the group who never smoked, the adjusted relative ratios (RRs) of gastric cancer for past and current smokers were $2.0(95 \%$ confidence interval $=1.1-3.7)$ and $2.1(95 \%$ confidence interval $=1.2-3.6)$, respectively. No association was observed between cigarette smoking and the risk of the undifferentiated type of distal gastric cancer except for a suggestive association with cardia cancer. For alcohol consumption, elevated risk was suggested only for cardia cancer of all histologic types, although the relationship failed to reach significance. Further analysis is needed for large-scale epidemiological observations, and particular DNA adducts in gastric cancer in particular locations may be related to some lifestyle factors. The differences seem to be more dependent on individual exposure to tobacco and alcohol, which are known to contribute to stomach cancer to some degree. The compound effects of several lifestyle factors ranging from educational records to diet were examined in a Japanese Public Health Cohort study [121]. Of course, there are other categories of DNA adducts or modifications that reflect the preferential distributions of cancer occurrence and are probably more related to the mechanistic injury of DNAs of the stomach causing subsequent mutations.

\section{Conclusions}

Although a peculiar preference among the locations in the stomach has been known, the precancerous changes at the molecular level in the landscape of the gastric mucosa did not explain the occurrence of gastric cancer. We showed a spatial adductomics approach as a possible approach to zero in on the local spot of the stomach for the initiation of cancer, but the findings presented here do not cover several bulky DNA adducts that are more familiar in experimental animal models. An extensive search for DNA adduct distribution in the stomach with mutational signatures caused by the initiating changes will help to produce a realistic view of human carcinogenesis and some preventive procedures that will become feasible in the future.

Author Contributions: Conceptualization, Y.I. and H.S.; formal analysis, Y.I.; investigation, I.O., Y.I., S.O., Y.M. (Yuto Matsushita) and T.Y.; clinical resources, F.T., H.M., S.S. (Shioto Suzuki), S.S. (Shohachi Suzuki), K.I., A.F., H.O. and K.M.; chemical resources, N.K. and Y.M. (Yoshitaka Matsushima); writing—original draft preparation, Y.I. and H.S.; writing—review and editing, Y.I. and H.S.; visualization, Y.I.; supervision, H.S. All authors have read and agreed to the published version of the manuscript.

Funding: This research was funded by JSPS KAKENHI Grant Numbers JP22659072, JP24659161, JP26670187, JP16K15256, AMED Grant Numbers JP19ck0106264, JP20ck0106545, Smoking Research Foundation and HUSM Grant-in-Aid.

Institutional Review Board Statement: The study was conducted according to the guidelines of the Declaration of Helsinki and approved by the Institutional Review Board of Hamamatsu University School of Medicine (IRB 20-011) and Iwata City Hospital.

Informed Consent Statement: Since the research included only residual pathology specimens, the requirement for informed consent was waived. The study design was approved by IRBs.

Data Availability Statement: The data presented in this study are available on request from the corresponding author.

Conflicts of Interest: The authors declare no conflict of interest. The funders had no role in the design of the study; in the collection, analyses, or interpretation of data; in the writing of the manuscript; or in the decision to publish the results.

\section{References}

1. International Agency for Research on Cancer/World Health Organization. Global Cancer Observatory. 2021. Available online: https://gco.iarc.fr/ (accessed on 30 April 2021).

2. Blair, V.R.; McLeod, M.; Carneiro, F.; Coit, D.G.; D’Addario, J.L.; van Dieren, J.M.; Harris, K.L.; Hoogerbrugge, N.; Oliveira, C.; van der Post, R.S.; et al. Hereditary diffuse gastric cancer: Updated clinical practice guidelines. Lancet Oncol. 2020, 21, e386-e397. [CrossRef] 
3. Haenszel, W.; Kurihara, M. Studies of Japanese migrants. I. Mortality from cancer and other diseases among Japanese in the United States. J. Natl. Cancer Inst. 1968, 40, 43-68. [PubMed]

4. Iwasaki, M.; Mameri, C.P.; Hamada, G.S.; Tsugane, S. Secular trends in cancer mortality among Japanese immigrants in the state of Sao Paulo, Brazil, 1979-2001. Eur. J. Cancer Prev. 2008, 17, 1-8. [CrossRef] [PubMed]

5. Hjerkind, K.V.; Qureshi, S.A.; Moller, B.; Weiderpass, E.; Deapen, D.; Kumar, B.; Ursin, G. Ethnic differences in the incidence of cancer in Norway. Int. J. Cancer 2017, 140, 1770-1780. [CrossRef]

6. Sugimura, T.; Fujimura, S. Tumour production in glandular stomach of rat by N-methyl-N'-nitro-N-nitrosoguanidine. Nature 1967, 216, 943-944. [CrossRef]

7. Matsukura, N.; Kawachi, T.; Sasajima, K.; Sano, T.; Sugimura, T.; Hirota, T. Induction of intestinal metaplasia in the stomachs of rats by N-methyl-N'-nitro-N-nitrosoguanidine. J. Natl. Cancer Inst. 1978, 61, 141-144. [CrossRef] [PubMed]

8. Uemura, N.; Okamoto, S.; Yamamoto, S.; Matsumura, N.; Yamaguchi, S.; Yamakido, M.; Taniyama, K.; Sasaki, N.; Schlemper, R.J. Helicobacter pylori infection and the development of gastric cancer. N. Engl. J. Med. 2001, 345, 784-789. [CrossRef]

9. Fukase, K.; Kato, M.; Kikuchi, S.; Inoue, K.; Uemura, N.; Okamoto, S.; Terao, S.; Amagai, K.; Hayashi, S.; Asaka, M.; et al. Effect of eradication of Helicobacter pylori on incidence of metachronous gastric carcinoma after endoscopic resection of early gastric cancer: An open-label, randomised controlled trial. Lancet 2008, 372, 392-397. [CrossRef]

10. Yamaoka, Y. Mechanisms of disease: Helicobacter pylori virulence factors. Nat. Rev. Gastroenterol. Hepatol. $2010,7,629-641$. [CrossRef]

11. Wynder, E.L.; Kmet, J.; Dungal, N.; Segi, M. An Epidemiological Investigation of Gastric Cancer. Cancer 1963, 16, 1461-1496. [CrossRef]

12. Ohnami, S.; Sato, Y.; Yoshimura, K.; Ohnami, S.; Sakamoto, H.; Aoki, K.; Ueno, H.; Ikeda, M.; Morizane, C.; Shimada, K.; et al. His595Tyr polymorphism in the methionine synthase reductase (MTRR) gene is associated with pancreatic cancer risk. Gastroenterology 2008, 135, 477-488. [CrossRef] [PubMed]

13. Saeki, N.; Saito, A.; Choi, I.J.; Matsuo, K.; Ohnami, S.; Totsuka, H.; Chiku, S.; Kuchiba, A.; Lee, Y.S.; Yoon, K.A.; et al. A functional single nucleotide polymorphism in mucin 1, at chromosome 1q22, determines susceptibility to diffuse-type gastric cancer. Gastroenterology 2011, 140, 892-902. [CrossRef]

14. Tanikawa, C.; Kamatani, Y.; Toyoshima, O.; Sakamoto, H.; Ito, H.; Takahashi, A.; Momozawa, Y.; Hirata, M.; Fuse, N.; TakaiIgarashi, T.; et al. Genome-wide association study identifies gastric cancer susceptibility loci at 12q24.11-12 and 20q11.21. Cancer Sci. 2018, 109, 4015-4024. [CrossRef]

15. Sakamoto, H.; Yoshimura, K.; Saeki, N.; Katai, H.; Shimoda, T.; Matsuno, Y.; Saito, D.; Sugimura, H.; Tanioka, F.; Shunji, K.; et al. Genetic variation in PSCA is associated with susceptibility to diffuse-type gastric cancer. Nat. Genet. 2008, 40, 730-740. [CrossRef]

16. Haenszel, W.; Kurihara, M.; Segi, M.; Lee, R.K. Stomach cancer among Japanese in Hawaii. J. Natl. Cancer Inst. 1972, 49, 969-988.

17. Iwasaki, M.; Mameri, C.P.; Hamada, G.S.; Tsugane, S. Cancer mortality among Japanese immigrants and their descendants in the state of Sao Paulo, Brazil, 1999-2001. Jpn. J. Clin. Oncol. 2004, 34, 673-680. [CrossRef] [PubMed]

18. Furuta, T.; El-Omar, E.M.; Xiao, F.; Shirai, N.; Takashima, M.; Sugimura, H. Interleukin 1beta polymorphisms increase risk of hypochlorhydria and atrophic gastritis and reduce risk of duodenal ulcer recurrence in Japan. Gastroenterology 2002, 123, 92-105. [CrossRef] [PubMed]

19. Tsugane, S.; Akabane, M.; Inami, T.; Matsushima, S.; Ishibashi, T.; Ichinowatari, Y.; Miyajima, Y.; Watanabe, S. Urinary salt excretion and stomach cancer mortality among four Japanese populations. Cancer Causes Control. 1991, 2, 165-168. [CrossRef] [PubMed]

20. Merliss, R.R. Talc-treated rice and Japanese stomach cancer. Science 1971, 173, 1141-1142. [CrossRef] [PubMed]

21. Hill, M.J. Carcinogenesis of gastrointestinal cancer. Front. Gastrointest. Res. 1979, 4, 1-16. [CrossRef]

22. Wynder, E.L.; Reddy, B.S.; McCoy, G.D.; Weisburger, J.H.; Williams, G.M. Diet and cancer of the gastrointestinal tract. Adv. Intern. Med. 1977, 22, 397-419. [PubMed]

23. Lijinsky, W.; Reuber, M.D.; Blackwell, B.N. Carcinogenicity of nitrosotrialkylureas in Fischer 344 rats. J. Natl. Cancer Inst. 1980, 65, 451-453.

24. Sugimura, T.; Wakabayashi, K. Gastric carcinogenesis: Diet as a causative factor. Med. Oncol. Tumor Pharmacother. 1990, 7, 87-92. [CrossRef]

25. Hollstein, M.; Sidransky, D.; Vogelstein, B.; Harris, C.C. p53 mutations in human cancers. Science 1991, 253, 49-53. [CrossRef]

26. Tornaletti, S.; Pfeifer, G.P. Complete and tissue-independent methylation of CpG sites in the p53 gene: Implications for mutations in human cancers. Oncogene 1995, 10, 1493-1499.

27. Shiao, Y.H.; Palli, D.; Buzard, G.S.; Caporaso, N.E.; Amorosi, A.; Saieva, C.; Fraumeni, J.F., Jr.; Anderson, L.M.; Rice, J.M. Implications of p53 mutation spectrum for cancer etiology in gastric cancers of various histologic types from a high-risk area of central Italy. Carcinogenesis 1998, 19, 2145-2149. [CrossRef] [PubMed]

28. Tahara, T.; Shibata, T.; Okamoto, Y.; Yamazaki, J.; Kawamura, T.; Horiguchi, N.; Okubo, M.; Nakano, N.; Ishizuka, T.; Nagasaka, M.; et al. Mutation spectrum of TP53 gene predicts clinicopathological features and survival of gastric cancer. Oncotarget 2016, 7, 42252-42260. [CrossRef] [PubMed]

29. Esteller, M.; Risques, R.A.; Toyota, M.; Capella, G.; Moreno, V.; Peinado, M.A.; Baylin, S.B.; Herman, J.G. Promoter hypermethylation of the DNA repair gene $\mathrm{O}(6)$-methylguanine-DNA methyltransferase is associated with the presence of G:C to A:T transition mutations in p53 in human colorectal tumorigenesis. Cancer Res. 2001, 61, 4689-4692. [PubMed] 
30. Klungland, A.; Laake, K.; Hoff, E.; Seeberg, E. Spectrum of mutations induced by methyl and ethyl methanesulfonate at the hprt locus of normal and tag expressing Chinese hamster fibroblasts. Carcinogenesis 1995, 16, 1281-1285. [CrossRef]

31. Richardson, K.K.; Richardson, F.C.; Crosby, R.M.; Swenberg, J.A.; Skopek, T.R. DNA base changes and alkylation following in vivo exposure of Escherichia coli to N-methyl-N-nitrosourea or N-ethyl-N-nitrosourea. Proc. Natl. Acad. Sci. USA 1987, 84, 344-348. [CrossRef] [PubMed]

32. Nagarajan, N.; Bertrand, D.; Hillmer, A.M.; Zang, Z.J.; Yao, F.; Jacques, P.E.; Teo, A.S.; Cutcutache, I.; Zhang, Z.; Lee, W.H.; et al. Whole-genome reconstruction and mutational signatures in gastric cancer. Genome Biol. 2012, 13, 1-10. [CrossRef]

33. Nik-Zainal, S.; Alexandrov, L.B.; Wedge, D.C.; Van Loo, P.; Greenman, C.D.; Raine, K.; Jones, D.; Hinton, J.; Marshall, J.; Stebbings, L.A.; et al. Mutational processes molding the genomes of 21 breast cancers. Cell 2012, 149, 979-993. [CrossRef]

34. Alexandrov, L.B.; Nik-Zainal, S.; Wedge, D.C.; Aparicio, S.A.; Behjati, S.; Biankin, A.V.; Bignell, G.R.; Bolli, N.; Borg, A.; Borresen-Dale, A.L.; et al. Signatures of mutational processes in human cancer. Nature 2013, 500, 415-421. [CrossRef]

35. Alexandrov, L.B.; Nik-Zainal, S.; Siu, H.C.; Leung, S.Y.; Stratton, M.R. A mutational signature in gastric cancer suggests therapeutic strategies. Nat. Commun. 2015, 6, 1-7. [CrossRef]

36. Liu, Y.; Sethi, N.S.; Hinoue, T.; Schneider, B.G.; Cherniack, A.D.; Sanchez-Vega, F.; Seoane, J.A.; Farshidfar, F.; Bowlby, R.; Islam, M.; et al. Comparative Molecular Analysis of Gastrointestinal Adenocarcinomas. Cancer Cell 2018, 33, 721-735.e28. [CrossRef]

37. Alexandrov, L.B.; Kim, J.; Haradhvala, N.J.; Huang, M.N.; Ng, A.W.T.; Wu, Y.; Boot, A.; Covington, K.R.; Gordenin, D.A.; Bergstrom, E.N.; et al. The repertoire of mutational signatures in human cancer. Nature 2020, 578, 94-101. [CrossRef] [PubMed]

38. Wong, S.S.; Kim, K.M.; Ting, J.C.; Yu, K.; Fu, J.; Liu, S.; Cristescu, R.; Nebozhyn, M.; Gong, L.; Yue, Y.G.; et al. Genomic landscape and genetic heterogeneity in gastric adenocarcinoma revealed by whole-genome sequencing. Nat. Commun. 2014, 5, 1-12. [CrossRef] [PubMed]

39. Huang, K.K.; Ramnarayanan, K.; Zhu, F.; Srivastava, S.; Xu, C.; Tan, A.L.K.; Lee, M.; Tay, S.; Das, K.; Xing, M.; et al. Genomic and Epigenomic Profiling of High-Risk Intestinal Metaplasia Reveals Molecular Determinants of Progression to Gastric Cancer. Cancer Cell 2018, 33, 137-150. [CrossRef] [PubMed]

40. Shimizu, T.; Marusawa, H.; Matsumoto, Y.; Inuzuka, T.; Ikeda, A.; Fujii, Y.; Minamiguchi, S.; Miyamoto, S.; Kou, T.; Sakai, Y.; et al. Accumulation of somatic mutations in TP53 in gastric epithelium with Helicobacter pylori infection. Gastroenterology 2014, 147, 407-417. [CrossRef]

41. Suzuki, A.; Katoh, H.; Komura, D.; Kakiuchi, M.; Tagashira, A.; Yamamoto, S.; Tatsuno, K.; Ueda, H.; Nagae, G.; Fukuda, S.; et al. Defined lifestyle and germline factors predispose Asian populations to gastric cancer. Sci. Adv. 2020, 6, eaav9778. [CrossRef]

42. Phillips, D.H.; Arlt, V.M. The ${ }^{32}$ P-postlabeling assay for DNA adducts. Nat. Protoc. 2007, 2, 2772-2781. [CrossRef]

43. Kanaly, R.A.; Hanaoka, T.; Sugimura, H.; Toda, H.; Matsui, S.; Matsuda, T. Development of the adductome approach to detect DNA damage in humans. Antioxid. Redox Signal. 2006, 8, 993-1001. [CrossRef] [PubMed]

44. Chou, P.H.; Kageyama, S.; Matsuda, S.; Kanemoto, K.; Sasada, Y.; Oka, M.; Shinmura, K.; Mori, H.; Kawai, K.; Kasai, H.; et al. Detection of lipid peroxidation-induced DNA adducts caused by 4-oxo-2(E)-nonenal and 4-oxo-2(E)-hexenal in human autopsy tissues. Chem. Res. Toxicol. 2010, 23, 1442-1448. [CrossRef]

45. Ishino, K.; Kato, T.; Kato, M.; Shibata, T.; Watanabe, M.; Wakabayashi, K.; Nakagama, H.; Totsuka, Y. Comprehensive DNA adduct analysis reveals pulmonary inflammatory response contributes to genotoxic action of magnetite nanoparticles. Int. J. Mol. Sci. 2015, 16, 3474-3492. [CrossRef]

46. Guo, J.; Villalta, P.W.; Turesky, R.J. Data-Independent Mass Spectrometry Approach for Screening and Identification of DNA Adducts. Anal. Chem. 2017, 89, 11728-11736. [CrossRef]

47. Carra, A.; Guidolin, V.; Dator, R.P.; Upadhyaya, P.; Kassie, F.; Villalta, P.W.; Balbo, S. Targeted High Resolution LC/MS(3) Adductomics Method for the Characterization of Endogenous DNA Damage. Front. Chem. 2019, 7, 658. [CrossRef]

48. Tretyakova, N.; Goggin, M.; Sangaraju, D.; Janis, G. Quantitation of DNA adducts by stable isotope dilution mass spectrometry. Chem. Res. Toxicol. 2012, 25, 2007-2035. [CrossRef] [PubMed]

49. Guo, J.; Turesky, R.J.; Tarifa, A.; DeCaprio, A.P.; Cooke, M.S.; Walmsley, S.J.; Villalta, P.W. Development of a DNA Adductome Mass Spectral Database. Chem. Res. Toxicol. 2020, 33, 852-854. [CrossRef]

50. Hemminki, K. Nucleic acid adducts of chemical carcinogens and mutagens. Arch. Toxicol. 1983, 52, 249-285. [CrossRef] [PubMed]

51. Matsuda, T.; Tao, H.; Goto, M.; Yamada, H.; Suzuki, M.; Wu, Y.; Xiao, N.; He, Q.; Guo, W.; Cai, Z.; et al. Lipid peroxidation-induced DNA adducts in human gastric mucosa. Carcinogenesis 2013, 34, 121-127. [CrossRef]

52. Goto, M.; Shinmura, K.; Matsushima, Y.; Ishino, K.; Yamada, H.; Totsuka, Y.; Matsuda, T.; Nakagama, H.; Sugimura, H. Human DNA glycosylase enzyme TDG repairs thymine mispaired with exocyclic etheno-DNA adducts. Free Radic. Biol. Med. 2014, 76, 136-146. [CrossRef] [PubMed]

53. Kavli, B.; Sundheim, O.; Akbari, M.; Otterlei, M.; Nilsen, H.; Skorpen, F.; Aas, P.A.; Hagen, L.; Krokan, H.E.; Slupphaug, G. hUNG2 is the major repair enzyme for removal of uracil from U:A matches, U:G mismatches, and U in single-stranded DNA, with hSMUG1 as a broad specificity backup. J. Biol. Chem. 2002, 277, 39926-39936. [CrossRef]

54. Wolfe, A.E.; O'Brien, P.J. Kinetic mechanism for the flipping and excision of 1,N(6)-ethenoadenine by human alkyladenine DNA glycosylase. Biochemistry 2009, 48, 11357-11369. [CrossRef] [PubMed]

55. Wu, X.; Zhang, Y. TET-mediated active DNA demethylation: Mechanism, function and beyond. Nat. Rev. Genet. 2017, 18, 517-534. [CrossRef] [PubMed] 
56. Du, C.; Kurabe, N.; Matsushima, Y.; Suzuki, M.; Kahyo, T.; Ohnishi, I.; Tanioka, F.; Tajima, S.; Goto, M.; Yamada, H.; et al. Robust quantitative assessments of cytosine modifications and changes in the expressions of related enzymes in gastric cancer. Gastric Cancer 2015, 18, 516-525. [CrossRef]

57. Ohnishi, I.; Iwashita, Y.; Matsushita, Y.; Ohtsuka, S.; Yamashita, T.; Inaba, K.; Fukazawa, A.; Ochiai, H.; Matsumoto, K.; Kurono, N.; et al. Mass spectrometric profiling of DNA adducts in the human stomach associated with damage fromenvironmental factors. Genes Environ. 2021, 43, 1-13. [CrossRef]

58. Xiong, J.; Ye, T.T.; Ma, C.J.; Cheng, Q.Y.; Yuan, B.F.; Feng, Y.Q. N 6-Hydroxymethyladenine: A hydroxylation derivative of N6-methyladenine in genomic DNA of mammals. Nucleic Acids Res. 2019, 47, 1268-1277. [CrossRef]

59. Lauren, P. The Two Histological Main Types of Gastric Carcinoma: Diffuse and So-Called Intestinal-Type Carcinoma. An Attempt at a Histo-Clinical Classification. Acta Pathol. Microbiol. Scand. 1965, 64, 31-49. [CrossRef]

60. WHO. Digestive System Tumours, 5th ed.; International Agency for Research on Cancer: Lyon, France, 2019.

61. Guo, R.J.; Arai, H.; Kitayama, Y.; Igarashi, H.; Hemmi, H.; Arai, T.; Hanai, H.; Sugimura, H. Microsatellite instability of papillary subtype of human gastric adenocarcinoma and hMLH1 promoter hypermethylation in the surrounding mucosa. Pathol. Int. 2001, 51, 240-247. [CrossRef]

62. Song, J.P.; Kitayama, Y.; Igarashi, H.; Guo, R.J.; Wang, Y.J.; Kobayashi, T.; Konno, H.; Kataoka, H.; Tanaka, M.; Sugimura, H. Centromere numerical abnormality in the papillary, papillotubular type of early gastric cancer, a further characterization of a subset of gastric cancer. Int. J. Oncol. 2002, 21, 1205-1211. [CrossRef]

63. Chan, K.; Brown, I.S.; Kyle, T.; Lauwers, G.Y.; Kumarasinghe, M.P. Chief cell-predominant gastric polyps: A series of 12 cases with literature review. Histopathology 2016, 68, 825-833. [CrossRef]

64. Ushiku, T.; Shinozaki, A.; Shibahara, J.; Iwasaki, Y.; Tateishi, Y.; Funata, N.; Fukayama, M. SALL4 represents fetal gut differentiation of gastric cancer, and is diagnostically useful in distinguishing hepatoid gastric carcinoma from hepatocellular carcinoma. Am. J. Surg. Pathol. 2010, 34, 533-540. [CrossRef]

65. Japanese Gastric Cancer Association. Japanese classification of gastric carcinoma: 3rd English edition. Gastric Cancer 2011, 14, 101-112. [CrossRef]

66. Oota, K.; Sobin, L.H. Histological Typing of Gastric and Oesophageal Tumours, 1st ed.; World Health Organization: Geneva, Switzerland, 1977; Volume 18.

67. Japanese Gastric Cancer Association. Japanese gastric cancer treatment guidelines 2018 (5th edition). Gastric Cancer 2020, $24,1-21$.

68. Tan, P.; Yeoh, K.G. Genetics and Molecular Pathogenesis of Gastric Adenocarcinoma. Gastroenterology 2015, 149, 1153-1162. [CrossRef]

69. Wang, K.; Kan, J.; Yuen, S.T.; Shi, S.T.; Chu, K.M.; Law, S.; Chan, T.L.; Kan, Z.; Chan, A.S.; Tsui, W.Y.; et al. Exome sequencing identifies frequent mutation of ARID1A in molecular subtypes of gastric cancer. Nat. Genet. 2011, 43, 1219-1223. [CrossRef] [PubMed]

70. Kakiuchi, M.; Nishizawa, T.; Ueda, H.; Gotoh, K.; Tanaka, A.; Hayashi, A.; Yamamoto, S.; Tatsuno, K.; Katoh, H.; Watanabe, Y.; et al. Recurrent gain-of-function mutations of RHOA in diffuse-type gastric carcinoma. Nat. Genet. 2014, 46, 583-587. [CrossRef] [PubMed]

71. Wang, K.; Yuen, S.T.; Xu, J.; Lee, S.P.; Yan, H.H.; Shi, S.T.; Siu, H.C.; Deng, S.; Chu, K.M.; Law, S.; et al. Whole-genome sequencing and comprehensive molecular profiling identify new driver mutations in gastric cancer. Nat. Genet. 2014, 46, 573-582. [CrossRef] [PubMed]

72. The Cancer Genome Atlas Research Network. Comprehensive molecular characterization of gastric adenocarcinoma. Nature 2014, 513, 202-209. [CrossRef]

73. Xing, R.; Zhou, Y.; Yu, J.; Yu, Y.; Nie, Y.; Luo, W.; Yang, C.; Xiong, T.; Wu, W.K.K.; Li, Z.; et al. Whole-genome sequencing reveals novel tandem-duplication hotspots and a prognostic mutational signature in gastric cancer. Nat. Commun. 2019, 10, 1-13. [CrossRef]

74. Li, Z.; Gao, X.; Peng, X.; Chen, M.J.M.; Li, Z.; Wei, B.; Wen, X.; Wei, B.; Dong, Y.; Bu, Z.; et al. Multi-omics characterization of molecular features of gastric cancer correlated with response to neoadjuvant chemotherapy. Sci. Adv. 2020, 6, eaay4211. [CrossRef]

75. Wang, R.; Dang, M.; Harada, K.; Han, G.; Wang, F.; Pizzi, M.P.; Zhao, M.; Tatlonghari, G.; Zhang, S.; Hao, D.; et al. Single-cell dissection of intratumoral heterogeneity and lineage diversity in metastatic gastric adenocarcinoma. Nat. Med. 2021, 27, 141-151. [CrossRef]

76. Song, L.; Song, M.; Camargo, M.C.; Van Duine, J.; Williams, S.; Chung, Y.; Kim, K.M.; Lissowska, J.; Sivins, A.; Gao, W.; et al. Identification of anti-Epstein-Barr virus (EBV) antibody signature in EBV-associated gastric carcinoma. Gastric. Cancer 2021, 24, 858-867. [CrossRef]

77. Okabe, A.; Huang, K.K.; Matsusaka, K.; Fukuyo, M.; Xing, M.; Ong, X.; Hoshii, T.; Usui, G.; Seki, M.; Mano, Y.; et al. Cross-species chromatin interactions drive transcriptional rewiring in Epstein-Barr virus-positive gastric adenocarcinoma. Nat. Genet. 2020, 52, 919-930. [CrossRef]

78. Re, V.; Brisotto, G.; Repetto, O.; De Zorzi, M.; Caggiari, L.; Zanussi, S.; Alessandrini, L.; Canzonieri, V.; Miolo, G.; Puglisi, F.; et al. Overview of Epstein-Barr-Virus-Associated Gastric Cancer Correlated with Prognostic Classification and Development of Therapeutic Options. Int. J. Mol. Sci. 2020, 21, 9400. [CrossRef] 
79. Chakraborty, P.; Ghatak, S.; Chenkual, S.; Pachuau, L.; Zohmingthanga, J.; Bawihtlung, Z.; Khenglawt, L.; Pautu, J.L.; Maitra, A.; Chhakchhuak, L.; et al. Panel of significant risk factors predicts early stage gastric cancer and indication of poor prognostic association with pathogens and microsatellite stability. Genes Environ. 2021, 43, 1-15. [CrossRef]

80. Slaughter, D.P.; Southwick, H.W.; Smejkal, W. Field cancerization in oral stratified squamous epithelium; clinical implications of multicentric origin. Cancer 1953, 6, 963-968. [CrossRef]

81. Lochhead, P.; Chan, A.T.; Nishihara, R.; Fuchs, C.S.; Beck, A.H.; Giovannucci, E.; Ogino, S. Etiologic field effect: Reappraisal of the field effect concept in cancer predisposition and progression. Mod. Pathol. 2015, 28, 14-29. [CrossRef] [PubMed]

82. Braakhuis, B.J.; Tabor, M.P.; Kummer, J.A.; Leemans, C.R.; Brakenhoff, R.H. A genetic explanation of Slaughter's concept of field cancerization: Evidence and clinical implications. Cancer Res. 2003, 63, 1727-1730. [PubMed]

83. Ushijima, T. Epigenetic field for cancerization. J. Biochem. Mol. Biol. 2007, 40, 142-150. [CrossRef] [PubMed]

84. McDonald, S.A.; Greaves, L.C.; Gutierrez-Gonzalez, L.; Rodriguez-Justo, M.; Deheragoda, M.; Leedham, S.J.; Taylor, R.W.; Lee, C.Y.; Preston, S.L.; Lovell, M.; et al. Mechanisms of field cancerization in the human stomach: The expansion and spread of mutated gastric stem cells. Gastroenterology 2008, 134, 500-510. [CrossRef] [PubMed]

85. Leedham, S.J.; Graham, T.A.; Oukrif, D.; McDonald, S.A.; Rodriguez-Justo, M.; Harrison, R.F.; Shepherd, N.A.; Novelli, M.R.; Jankowski, J.A.; Wright, N.A. Clonality, founder mutations, and field cancerization in human ulcerative colitis-associated neoplasia. Gastroenterology 2009, 136, 542-550. [CrossRef]

86. Pereira, A.; Moreira, F.; Vinasco-Sandoval, T.; Cunha, A.; Vidal, A.; Ribeiro-Dos-Santos, A.M.; Pinto, P.; Magalhaes, L.; Assumpcao, M.; Demachki, S.; et al. miRNome Reveals New Insights Into the Molecular Biology of Field Cancerization in Gastric Cancer. Front. Genet. 2019, 10, 592. [CrossRef] [PubMed]

87. Kakiuchi, N.; Ogawa, S. Clonal expansion in non-cancer tissues. Nat. Rev. Cancer 2021, 21, 239-256. [CrossRef] [PubMed]

88. Curtius, K.; Wright, N.A.; Graham, T.A. An evolutionary perspective on field cancerization. Nat. Rev. Cancer 2018, 18, 19-32. [CrossRef]

89. Kim, K.; Cho, Y.; Sohn, J.H.; Kim, D.H.; Do, I.G.; Lee, H.J.; Do, S.I.; Ahn, S.; Lee, H.W.; Chae, S.W. Clinicopathologic characteristics of early gastric cancer according to specific intragastric location. BMC Gastroenterol. 2019, 19, 1-8. [CrossRef] [PubMed]

90. Huang, Q.; Fang, C.; Shi, J.; Sun, Q.; Wu, H.; Gold, J.S.; Weber, H.C.; Guan, W.; Zhang, Y.; Yu, C.; et al. Differences in Clinicopathology of Early Gastric Carcinoma between Proximal and Distal Location in 438 Chinese Patients. Sci. Rep. 2015, 5, 1-12. [CrossRef]

91. Kang, D.H.; Choi, C.W.; Kim, H.W.; Park, S.B.; Kim, S.J.; Nam, H.S.; Ryu, D.G. Location characteristics of early gastric cancer treated with endoscopic submucosal dissection. Surg. Endosc. 2017, 31, 4673-4679. [CrossRef]

92. Bakhti, S.Z.; Latifi-Navid, S.; Zahri, S.; Yazdanbod, A. Inverse association of Helicobacter pylori cagPAI genotypes with risk of cardia and non-cardia gastric adenocarcinoma. Cancer Med. 2019, 8, 4928-4937. [CrossRef]

93. Yao, Q.; Qi, X.; Xie, S.H. Sex difference in the incidence of cardia and non-cardia gastric cancer in the United States, $1992-2014$. BMC Gastroenterol. 2020, 20, 1-7. [CrossRef]

94. Ghidini, M.; Donida, B.M.; Totaro, L.; Ratti, M.; Pizzo, C.; Benzoni, I.; Lomiento, D.; Aldighieri, F.; Toppo, L.; Ranieri, V.; et al. Prognostic factors associated with survival in a large cohort of gastric cancer patients resected over a decade at a single Italian center: The Cremona experience. Clin. Transl. Oncol. 2020, 22, 1-9. [CrossRef] [PubMed]

95. Butt, J.; Varga, M.G.; Wang, T.; Tsugane, S.; Shimazu, T.; Zheng, W.; Abnet, C.C.; Yoo, K.Y.; Park, S.K.; Kim, J.; et al. Smoking, Helicobacter Pylori Serology, and Gastric Cancer Risk in Prospective Studies from China, Japan, and Korea. Cancer Prev. Res. 2019, 12, 667-674. [CrossRef]

96. Pereira, S.A.; Antunes, A.M.M. Special Issue "Adductomics: Elucidating the Environmental Causes of Disease". High-Throughput 2019, 8, 17. [CrossRef]

97. Vidal, A.F.; Ribeiro-Dos-Santos, A.M.; Vinasco-Sandoval, T.; Magalhaes, L.; Pinto, P.; Anaissi, A.K.M.; Demachki, S.; de Assumpcao, P.P.; Dos Santos, S.E.B.; Ribeiro-Dos-Santos, A. The comprehensive expression analysis of circular RNAs in gastric cancer and its association with field cancerization. Sci. Rep. 2017, 7, 1-8. [CrossRef] [PubMed]

98. Hattori, N.; Ushijima, T. Epigenetic impact of infection on carcinogenesis: Mechanisms and applications. Genome Med. 2016, 8, 1-13. [CrossRef] [PubMed]

99. Kaneda, A.; Tsukamoto, T.; Takamura-Enya, T.; Watanabe, N.; Kaminishi, M.; Sugimura, T.; Tatematsu, M.; Ushijima, T. Frequent hypomethylation in multiple promoter $\mathrm{CpG}$ islands is associated with global hypomethylation, but not with frequent promoter hypermethylation. Cancer Sci. 2004, 95, 58-64. [CrossRef]

100. Kucab, J.E.; Zou, X.; Morganella, S.; Joel, M.; Nanda, A.S.; Nagy, E.; Gomez, C.; Degasperi, A.; Harris, R.; Jackson, S.P.; et al. A Compendium of Mutational Signatures of Environmental Agents. Cell 2019, 177, 821-836. [CrossRef] [PubMed]

101. Riva, L.; Pandiri, A.R.; Li, Y.R.; Droop, A.; Hewinson, J.; Quail, M.A.; Iyer, V.; Shepherd, R.; Herbert, R.A.; Campbell, P.J.; et al. The mutational signature profile of known and suspected human carcinogens in mice. Nat. Genet. 2020, 52, 1189-1197. [CrossRef]

102. Zhivagui, M.; Ng, A.W.T.; Ardin, M.; Churchwell, M.I.; Pandey, M.; Renard, C.; Villar, S.; Cahais, V.; Robitaille, A.; Bouaoun, L.; et al. Experimental and pan-cancer genome analyses reveal widespread contribution of acrylamide exposure to carcinogenesis in humans. Genome Res. 2019, 29, 521-531. [CrossRef]

103. Totsuka, Y.; Lin, Y.; He, Y.; Ishino, K.; Sato, H.; Kato, M.; Nagai, M.; Elzawahry, A.; Totoki, Y.; Nakamura, H.; et al. DNA Adductome Analysis Identifies N-Nitrosopiperidine Involved in the Etiology of Esophageal Cancer in Cixian, China. Chem. Res. Toxicol. 2019, 32, 1515-1527. [CrossRef] 
104. Zavadil, J.; Rozen, S.G. Experimental Delineation of Mutational Signatures is an Essential Tool in Cancer Epidemiology and Prevention. Chem. Res. Toxicol. 2019, 32, 2153-2155. [CrossRef]

105. Totsuka, Y.; Watanabe, M.; Lin, Y. New horizons of DNA adductome for exploring environmental causes of cancer. Cancer Sci. 2021, 112, 7. [CrossRef] [PubMed]

106. Meier, B.; Cooke, S.L.; Weiss, J.; Bailly, A.P.; Alexandrov, L.B.; Marshall, J.; Raine, K.; Maddison, M.; Anderson, E.; Stratton, M.R.; et al. C. elegans whole-genome sequencing reveals mutational signatures related to carcinogens and DNA repair deficiency. Genome Res. 2014, 24, 1624-1636. [CrossRef] [PubMed]

107. Meier, B.; Volkova, N.V.; Hong, Y.; Schofield, P.; Campbell, P.J.; Gerstung, M.; Gartner, A. Mutational signatures of DNA mismatch repair deficiency in C. elegans and human cancers. Genome Res. 2018, 28, 666-675. [CrossRef] [PubMed]

108. Volkova, N.V.; Meier, B.; Gonzalez-Huici, V.; Bertolini, S.; Gonzalez, S.; Vohringer, H.; Abascal, F.; Martincorena, I.; Campbell, P.J.; Gartner, A.; et al. Mutational signatures are jointly shaped by DNA damage and repair. Nat. Commun. 2020, 11, 1-15. [CrossRef]

109. Zou, X.; Koh, G.; Nanda, A.; Degasperi, A.; Urgo, K.; Roumeliotis, T.; Agu, C.; Side, L.; Brice, G.; Perez-Aloso, V.; et al. Dissecting mutational mechanisms underpinning signatures caused.by replication errors and endogenous DNA damage. BiorXiv 2020. [CrossRef]

110. Hu, J.; Adar, S.; Selby, C.P.; Lieb, J.D.; Sancar, A. Genome-wide analysis of human global and transcription-coupled excision repair of UV damage at single-nucleotide resolution. Genes Dev. 2015, 29, 948-960. [CrossRef]

111. Hu, J.; Li, W.; Adebali, O.; Yang, Y.; Oztas, O.; Selby, C.P.; Sancar, A. Genome-wide mapping of nucleotide excision repair with XR-seq. Nat. Protoc. 2019, 14, 248-282. [CrossRef] [PubMed]

112. Li, W.; Hu, J.; Adebali, O.; Adar, S.; Yang, Y.; Chiou, Y.Y.; Sancar, A. Human genome-wide repair map of DNA damage caused by the cigarette smoke carcinogen benzo[a]pyrene. Proc. Natl. Acad. Sci. USA 2017, 114, 6752-6757. [CrossRef] [PubMed]

113. Vaughn, C.M.; Selby, C.P.; Yang, Y.; Hsu, D.S.; Sancar, A. Genome-wide single-nucleotide resolution of oxaliplatin-DNA adduct repair in drug-sensitive and -resistant colorectal cancer cell lines. J. Biol. Chem. 2020, 295, 7584-7594. [CrossRef]

114. Yang, Y.; Hu, J.; Selby, C.P.; Li, W.; Yimit, A.; Jiang, Y.; Sancar, A. Single-nucleotide resolution analysis of nucleotide excision repair of ribosomal DNA in humans and mice. J. Biol. Chem. 2019, 294, 210-217. [CrossRef]

115. Yimit, A.; Adebali, O.; Sancar, A.; Jiang, Y. Differential damage and repair of DNA-adducts induced by anti-cancer drug cisplatin across mouse organs. Nat. Commun. 2019, 10,1-11. [CrossRef] [PubMed]

116. Flusberg, B.A.; Webster, D.R.; Lee, J.H.; Travers, K.J.; Olivares, E.C.; Clark, T.A.; Korlach, J.; Turner, S.W. Direct detection of DNA methylation during single-molecule, real-time sequencing. Nat. Methods 2010, 7, 461-465. [CrossRef] [PubMed]

117. Clark, T.A.; Spittle, K.E.; Turner, S.W.; Korlach, J. Direct detection and sequencing of damaged DNA bases. Genome Integr. 2011, 2, 1-9. [CrossRef]

118. Georgieva, D.; Liu, Q.; Wang, K.; Egli, D. Detection of base analogs incorporated during DNA replication by nanopore sequencing. Nucleic Acids Res. 2020, 48, e88. [CrossRef] [PubMed]

119. Nookaew, I.; Jenjaroenpun, P.; Du, H.; Wang, P.; Wu, J.; Wongsurawat, T.; Moon, S.H.; Huang, E.; Wang, Y.; Boysen, G. Detection and Discrimination of DNA Adducts Differing in Size, Regiochemistry, and Functional Group by Nanopore Sequencing. Chem. Res. Toxicol. 2020, 33, 2944-2952. [CrossRef] [PubMed]

120. Sasazuki, S.; Sasaki, S.; Tsugane, S.; Japan Public Health Center Study, G. Cigarette smoking, alcohol consumption and subsequent gastric cancer risk by subsite and histologic type. Int. J. Cancer 2002, 101, 560-566. [CrossRef] [PubMed]

121. Tsugane, S.; Fahey, M.T.; Sasaki, S.; Baba, S. Alcohol consumption and all-cause and cancer mortality among middle-aged Japanese men: Seven-year follow-up of the JPHC study Cohort, I. Japan Public Health Center. Am. J. Epidemiol. 1999, 150, 1201-1207. [CrossRef] [PubMed] 